\title{
Weak effect of trans-10, cis-12-conjugated linoleic acid on body fat accumulation in adult hamsters
}

\author{
Jonatan Miranda, Itziar Churruca, Alfredo Fernández-Quintela, Victor Manuel Rodríguez, \\ María Teresa Macarulla, Edurne Simón and María Puy Portillo* \\ Department of Nutrition and Food Science, University of País Vasco, Paseo de la Universidad 7, 01006 Vitoria, Spain
}

(Received 7 January 2009 - Revised 3 June 2009 - Accepted 9 June 2009 - First published online 21 July 2009)

It has been proposed that young animals and subjects are more responsive to conjugated linoleic acid (CLA) than the adults. Nevertheless, there is very little information concerning the effectiveness of CLA in adult animals. In the present study we aimed to explore the effects of trans-10, cis-12-CLA on body fat accumulation in adult hamsters, as well as on some of the molecular mechanisms described in young animals as responsible for the CLA body fat-lowering effect, such as lipogenesis, lipoprotein lipase (LPL)-mediated fat uptake and thermogenesis. The experiment was conducted with sixteen adult male Syrian Golden hamsters (aged 8 months) fed a high-fat diet supplemented or not with $0.5 \%$ trans-10, cis-12-CLA for 6 weeks. Acetyl-CoA carboxylase (ACX), fatty acid synthase (FAS), LPL, PPAR $\gamma$, sterol regulatory element-binding protein (SREBP)-1a and SREBP-1c expressions were assessed in subcutaneous and perirenal adipose tissues by real-time RT-PCR. Total and heparin-releasable LPL activities were determined in subcutaneous adipose tissue by fluorimetry and FAS activity by spectrophotometry. Uncoupling protein-1 (UCP1) expression in interscapular brown adipose tissue was assessed by Western blot. Hamsters fed the trans-10, cis-12-CLA diet showed a significant reduction in subcutaneous adipose tissue. No changes were observed in the expression of ACX, FAS, LPL, SREBP-1a, SREBP-1c and PPAR $\gamma$, nor in total and heparin-releasable LPL and FAS activities. Trans-10, cis-12-CLA induced a significant increase in the amount of UCP1. These results suggest a low responsiveness to trans-10, cis-12-CLA in adults, lower than that in young hamsters. One of the reasons explaining this difference is the lack of effect on LPL.

Conjugated linoleic acid: Adult hamsters: Adipose tissue

Numerous studies performed in experimental animals, mainly in rodents, have demonstrated the fat-lowering effect of the trans-10, cis-12 isomer of conjugated linoleic acid $(\mathrm{CLA})^{(1-3)}$. In contrast, the effectiveness of CLA on humans is controversial. Whereas some authors have observed reductions in body fat accumulation, others have not noticed this effect ${ }^{(4-6)}$. Moreover, this effect, when it is observed, is less prominent than when it is found in rodents.

Various reasons could explain this difference between humans and rodents ${ }^{(7)}$. One is related to the dose of CLA. Whereas in rodent experiments animals fed diets supplemented with $0 \cdot 25-2 \mathrm{~g}$ CLA/ $100 \mathrm{~g}$ diet received CLA amounts close to $210-250 \mathrm{mg}$ CLA $/ \mathrm{kg}$ body weight, in human studies, volunteers received $1.4-6 \cdot 8 \mathrm{~g} / \mathrm{d}$. For a $70 \mathrm{~kg}$ adult, this represents $20-97 \mathrm{mg}$ CLA/ $\mathrm{kg}$ body weight. These doses are clearly lower than those used in rodents.

Another important reason refers to age and maturity stage. It has been proposed that young animals and subjects are probably more responsive to CLA than adults, due to their growing status or to other metabolic situations. With regard to this issue it should be pointed out that while human studies have addressed adults, the vast majority of the experiments on rodents have been conducted with growing animals.

There is very little information concerning the effectiveness of CLA in adult animals which are not anabolic. Mirand et $a l .{ }^{(8)}$ and Faulconnier et al. ${ }^{(9)}$ reported that adult rats were not responsive to the fat-to-lean partitioning effect of CLA described in growing rats. In contrast, Park et al. ${ }^{(10)}$ observed a significant reduction in adipose tissue weight $(47 \%)$ as well as in the percentage of body fat $(45 \%)$ in mature female mice fed a CLA mixture. In line with these results, Miner et al. ${ }^{(11)}$ also found significant reductions in adipose tissue weight $(50-67 \%)$ in adult mice fed a CLA mixture. It could be hypothesised that the effect on ageing depends on animal species.

In a previous study we observed that adult hamsters were less responsive to CLA feeding than young hamsters ${ }^{(12)}$. Although the reasons justifying this fact still remain unclear, differences in some of the molecular mechanisms described as being responsible for the CLA body fat-lowering effect in young animals, such as lipogenesis and thermogenesis, can be hypothesised.

Abbreviations: ACX, acetyl-CoA carboxylase; cDNA, complementary DNA; CLA, conjugated linoleic acid; FAS, fatty acid synthase; HR-LPL, heparinreleasable lipoprotein lipase; IBAT, interscapular brown adipose tissue; LPL, lipoprotein lipase; SREBP, sterol regulatory element-binding protein; UCP1, uncoupling protein-1.

* Corresponding author: Dr María P. Portillo, fax +34945 013014, email mariapuy.portillo@ehu.es 
In adipose tissue the process of TAG synthesis, known as lipogenesis, occurs mainly through two different pathways: one of them is mediated by lipoprotein lipase (LPL) which is responsible for the release of NEFA derived from chylomicrons and VLDL-TAG ${ }^{(13)}$. The enzyme is synthesised and secreted by adipocytes, and anchored to the luminal surface of the capillary endothelial cells. The resulting NEFA and monoacylglycerols are then available for re-esterification and storage. Thus, LPL activity plays a key role in controlling lipid deposition in adipose tissue. The transcription of LPL is controlled by PPAR $\gamma$, a transcriptional factor highly expressed in adipose tissue ${ }^{(14)}$. Its activation thus promotes lipid storage ${ }^{(15)}$.

The alternative pathway for lipogenesis involves the synthesis of fatty acids from glucose and is known as de novo lipogenesis. The relative importance of these two pathways is mainly dependent on the diet. The transcription of genes encoding lipogenic enzymes, such as fatty acid synthase (FAS) and acetyl-CoA carboxylase (ACX), is controlled by a family of membrane-bound transcriptional factors designated as sterol regulatory element-binding proteins $(\text { SREBP })^{(16)}$. Three types of SREBP have been identified. It has been shown that SREBP-1a and SREBP-1c, both derived from a single gene, participate in the regulation of the gene expression of enzymes involved in fatty acid synthesis ${ }^{(17,18)}$.

An important component of energy expenditure is nonshivering thermogenesis which, in rodents, takes place mostly in brown adipose tissue and is based on the functionality of uncoupling protein-1 (UCP1), a member of the inner mitochondrial membrane transporters that allows the dissipation as heat of the proton gradient generated by the oxidation of nutrients, mainly fatty acids ${ }^{(19)}$. This protein allows heat production by uncoupling respiration from ATP synthesis.

Thus, in the present study we aimed to explore the effects of trans-10, cis-12-CLA on the activity and expression of lipogenic enzymes, as well as on the expression of their controlling transcriptional factors in adult hamsters. The effect on the thermogenin UCP1 in brown adipose tissue was also assessed.

\section{Methods and procedures}

\section{Animals, diets and experimental design}

The experiment was conducted with sixteen adult male Syrian Golden hamsters (aged 8 months; initial body weight 167 (SEM 5) g) purchased from Harlan Ibérica (Barcelona, Spain) and its protocol was approved by the Animal Experimentation Ethics Committee of the University of the Basque Country. Animals were individually housed in polycarbonate metabolism cages (Techniplast Gazzada, Guguggiate, Italy), placed in an air-conditioned room (22 (SEM 2) ${ }^{\circ} \mathrm{C}$ ) with a $12 \mathrm{~h}$ light-dark cycle. All manipulations with animals were in accordance with the 'Guide for the Care and Use of Laboratory Animals' as promulgated by the National Institutes of Health. After a $6 \mathrm{~d}$ adaptation period, hamsters were randomly divided into two groups of eight animals each and fed for 6 weeks semi-purified high-fat diets consisting of $200 \mathrm{~g}$ casein/ $\mathrm{kg}$ (Sigma, St Louis, MO, USA), $4 \mathrm{~g}$ L-methionine $/ \mathrm{kg}$ (Sigma), $200 \mathrm{~g}$ wheat starch $/ \mathrm{kg}$ (Vencasser, Bilbao, Spain), $404 \mathrm{~g}$ sucrose/kg (local market),
$100 \mathrm{~g}$ palm oil/kg (Agra, Leioa, Spain), $30 \mathrm{~g}$ cellulose $/ \mathrm{kg}$ (Vencasser), $1 \mathrm{~g}$ cholesterol/kg (Sigma), $4 \mathrm{~g}$ choline $\mathrm{HCl} / \mathrm{kg}$ (Sigma), and supplemented with $0.5 \%$ linoleic acid (used as a control) or $0.5 \%$ trans-10, cis-12-CLA (Natural Lipids Ltd, Hovdebygda, Norway). Vitamin $(11 \mathrm{~g} / \mathrm{kg})$ and mineral $(40 \mathrm{~g} / \mathrm{kg})$ mixes were formulated according to American Institute of Nutrition (AIN)-93 guidelines ${ }^{(20)}$ and supplied by ICN Pharmaceuticals (Costa Mesa, CA, USA). The experimental diets were freshly prepared once per week, gassed with $\mathrm{N}_{2}$ and stored at $0-4{ }^{\circ} \mathrm{C}$ to avoid rancidity. All animals had free access to food and water. Food intake and body weight were measured daily.

At the end of the experimental period animals were killed under anaesthesia (chloral hydrate) by cardiac exsanguination. White adipose tissue from different anatomical locations (epididymal, perirenal and subcutaneous) and brown adipose tissue from the interscapular area (IBAT) were dissected, weighed and immediately frozen.

\section{Enzyme activities}

For total LPL activity determination, homogenates of subcutaneous adipose tissues $(250 \mathrm{mg})$ were prepared in $750 \mu \mathrm{l}$ of $10 \mathrm{mM}$-HEPES buffer ( $\mathrm{pH} 7 \cdot 5$ ) containing $1 \mathrm{mM}$-dithiothreitol, $1 \mathrm{~mm}$-EDTA, $250 \mathrm{~mm}$-sucrose and heparin $(2 \mathrm{~g} / \mathrm{l})$ and used as the enzyme source. Soluble protein in homogenates was determined using bovine serum albumin as the standard ${ }^{(21)}$. For heparin-releasable LPL (HR-LPL) activity determination, the enzyme source was obtained by incubating $250 \mathrm{mg}$ subcutaneous adipose tissue in $750 \mu \mathrm{l}$ of $10 \mathrm{~mm}$-HEPES buffer (described above) at $37^{\circ} \mathrm{C}$ during $30 \mathrm{~min}$. Enzyme activity was assessed following the method described by Nilsson \& Schotz with modifications, as previously described ${ }^{(22)}$. LPL (total and HR-LPL) activity was calculated by subtracting non-LPL lipolytic activity in the presence of $\mathrm{NaCl}$ from the total lipolytic activity determined without $\mathrm{NaCl}$. Total LPL activity was expressed as nmol oleate released/min per $\mathrm{mg}$ protein and HR-LPL as nmol oleate released/min per $\mathrm{g}$ tissue.

For FAS analysis, samples of subcutaneous adipose tissue $(1.0 \mathrm{~g})$ were homogenised in $2.5 \mathrm{ml}$ of buffer ( $\mathrm{pH} 7.6)$ containing $150 \mathrm{~mm}-\mathrm{KCl}, 1 \mathrm{mM}-\mathrm{MgCl}_{2}, 10 \mathrm{~mm}-\mathrm{N}$-acetyl-cysteine and $0.5 \mathrm{~mm}$-dithiothreitol. After centrifugation at $100000 \mathrm{~g}$ for $40 \mathrm{~min}$ at $4^{\circ} \mathrm{C}$, the supernatant fraction was used for enzyme activity quantification that was performed by using the rate of malonyl-CoA-dependent NADPH oxidation, according to the method of Lynen ${ }^{(23)}$. Soluble protein in homogenates was determined using bovine serum albumin as the standard $^{(21)}$. Enzyme activity was expressed as nmol $\mathrm{NADPH}$ consumed/min per $\mathrm{mg}$ protein.

\section{Extraction and analysis of RNA and quantification by reverse transcription-polymerase chain reaction}

Total RNA was isolated from $100 \mathrm{mg}$ of either subcutaneous or perirenal adipose tissues using Trizol (Invitrogen, Carlsbad, CA, USA) according to the manufacturer's instructions. RNA samples were then treated with a DNA-free kit (Ambion; Applied Biosystems, Foster City, CA, USA) to remove any contamination with genomic DNA. The yield and quality of the RNA were assessed by measuring absorbance at 260,270, 280 and $310 \mathrm{~nm}$ and by electrophoresis 
on $1.3 \%$ agarose gels. A quantity of $1.5 \mu \mathrm{g}$ of total RNA of each sample was reverse-transcribed to first-strand complementary DNA (cDNA) using an iScript ${ }^{\mathrm{TM}}$ cDNA Synthesis Kit (Bio-Rad, Hercules, CA, USA).

Relative ACX, FAS, SREBP-1a, SREBP-1c, LPL and PPAR $y$ mRNA levels were quantified using real-time PCR with an iCycler $^{\mathrm{TM}}-\mathrm{MyiQ}^{\mathrm{TM}}$ Real-time PCR Detection System (Bio-Rad). $\beta$-Actin mRNA levels were similarly measured and served as the reference gene.

SREBP-1c, LPL, PPAR $\gamma$ and $\beta$-actin were quantified by SYBR $^{\circledR}$ Green chemical real-time PCR. A quantity of $0.1 \mu \mathrm{l}$ of each cDNA was added to the PCR reagent mixture $\left(\right.$ SYBR $^{\circledR}$ Green Master Mix; Applied Biosystems), with the upstream and downstream primers ( $300 \mathrm{~nm}$ each). The PCR parameters were as follows: initial $2 \mathrm{~min}$ at $50^{\circ} \mathrm{C}$, denaturation at $95^{\circ} \mathrm{C}$ for $10 \mathrm{~min}$ followed by forty cycles of denaturation at $95^{\circ} \mathrm{C}$ for $15 \mathrm{~s}$ and combined annealing and extension at $60^{\circ} \mathrm{C}$ for $1 \mathrm{~min}$ for SREBP-1c, LPL and $\beta$-actin, and $63.5^{\circ} \mathrm{C}$ for 1 min for PPAR $\gamma$.

ACX, FAS, SREBP-1a and $\beta$-actin were quantified by Taqman real-time PCR. A quantity of $1 \mu l$ of each cDNA was added to the PCR reagent mixture (Premix Ex Taq ${ }^{\mathrm{TM}}$; Takara Bio Inc., Shiga, Japan), with the upstream (200 nMFAS, SREBP-1a and $\beta$-actin and $300 \mathrm{~nm}-\mathrm{ACX}$ ) and downstream (200 nM-ACX and $\beta$-actin and $300 \mathrm{~nm}-\mathrm{FAS}$ and SREBP-1a) primers and probes $(0.5 \mu \mathrm{M}-\beta$-actin, $2.5 \mu \mathrm{M}$ ACX and FAS and $5 \mu \mathrm{M}$-SREBP-1a). The PCR parameters were as follows: initial denaturation at $95^{\circ} \mathrm{C}$ for $5 \mathrm{~s}$ followed by forty cycles of denaturation at $95^{\circ} \mathrm{C}$ for $5 \mathrm{~s}$ and combined annealing and extension at $60.7^{\circ} \mathrm{C}$ for $30 \mathrm{~s}$ for ACX, $60^{\circ} \mathrm{C}$ for $60 \mathrm{~s}$ for FAS and SREBP-1a and $64^{\circ} \mathrm{C}$ for $30 \mathrm{~s}$ for $\beta$-actin.

Information concerning specific sense and antisense primers and probes is shown in Table 1. All sample mRNA levels were normalised to the values of $\beta$-actin and the results expressed as fold changes of threshold cycle $(\mathrm{Ct})$ value relative to controls using the $2^{-\Delta \Delta \mathrm{Ct}}$ method ${ }^{(24)}$.

Uncoupling protein-1 Western blot analysis in interscapular brown adipose tissue

Samples of IBAT $(100 \mathrm{mg})$ were homogenised with cellular PBS (150 mM-NaCl; $3 \mathrm{~mm}-\mathrm{KCl} ; 3 \mathrm{~mm}-\mathrm{NaH}_{2} \mathrm{PO}_{4} ; 7.5 \mathrm{~mm}-$ $\mathrm{Na}_{2} \mathrm{HPO}_{4} ; \quad 1 \mu \mathrm{M}$-phenylmethanesulfonylfluoride; $10 \mu \mathrm{M}$ iodoacetamide; $\mathrm{pH}$ 7.4) and their protein concentration was determined by using the Bradford method ${ }^{(21)}$. Protein $(30 \mu \mathrm{g})$ was separated by SDS-PAGE in a $10 \%$ gel at $150 \mathrm{~V}$ for $1 \mathrm{~h}$, and was electrotransferred to a polyvinylidene difluoride membrane (Bio-Rad) at $90 \mathrm{~V}$ during $70 \mathrm{~min}$. Blots were blocked with $5 \%$ powdered non-fat milk in PBS with $0.1 \%$ Tween-20 (PBS-Tween) for $1 \mathrm{~h}$ and incubated with specific rabbit antibodies against UCP1 (1:3000) (SC-6529; Santa Cruz Biotechnology, Inc., Santa Cruz, CA, USA).

Blots were washed in PBS-Tween and incubated with antirabbit horseradish peroxidase-conjugated secondary antibody (1:20000) for $1 \mathrm{~h}$. After that, blots were washed in PBSTween and developed by chemiluminescent detection using a standard kit (ECL Kit; Amersham plc, Little Chalfont, Bucks, UK). Band intensity was measured by densitometric scanning (Bio-Rad GS-700 Imaging Densitometer) and analysed with Multi-Analyst/PC 1.1 software (Bio-Rad). Monoclonal anti-mouse $\beta$-actin (Amersham NA931VS, dilution 


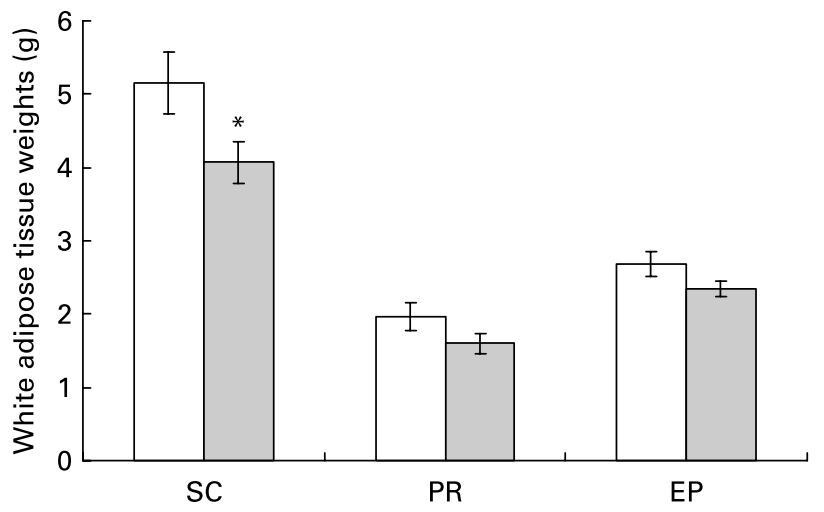

Fig. 1. Subcutaneous (SC), perirenal (PR) and epididymal (EP) adipose tissue weights from adult hamsters (eight per group) fed on the experimental diets ( $\square$, linoleic acid diet, used as a control; $\square$, conjugated linoleic acidsupplemented diet) for 6 weeks. Values are means, with standard errors represented by vertical bars. ${ }^{\star}$ Mean value was significantly different from that of the linoleic acid group $(P<0.05)$.

1:2000) antibody was used as a loading control to normalise the signal obtained for brown adipose tissue UCP1.

\section{Statistical analysis}

Results are presented as mean values with their standard errors. Statistical analysis was performed using SPSS (version 13.0; SPSS Inc., Chicago, IL, USA). Data were analysed by Student's $t$ test. Statistical significance was set up at the $P<0.05$ level.

\section{Results}

\section{Body weight, food intake and white adipose tissue weights}

As we previously reported ${ }^{(25)}$, no significant differences either in food intake or in final body weight were found between both experimental groups. Hamsters fed the trans-10, cis12-CLA diet showed reduced epididymal $(-12.3 \%)$ and perirenal $(-18.4 \%)$ adipose tissue weights, but this effect did not reach statistical significance. In contrast, subcutaneous fat pad weights were significantly lower in hamsters after CLA feeding $(-21.0 \% ; P<0.05)$ (Fig. 1).

Enzyme and transcription factor expressions in adipose tissues

No significant changes were induced by CLA feeding either in the expression of lipogenic enzymes (ACX and FAS) or in the expression of the transcriptional factors regulating their activity, SREBP-1a and SREBP-1c (Table 2). With regard to LPL, the same situation was found; no changes were observed in the expression of the enzyme, or in PPAR $y$ (Table 2). This lack of changes refers to both subcutaneous and perirenal adipose tissues.

\section{Enzyme activities in subcutaneous adipose tissue}

CLA feeding did not induce significant changes in HR-LPL activity (2.87 (SEM 0.65) nmol oleate released/min per $\mathrm{g}$ tissue in the linoleic acid group v. 3.08 (SEM 0.65) nmol oleate released/min per $\mathrm{g}$ tissue in the CLA group). Moreover, no significant changes were observed between both experimental groups in total LPL or FAS activities (Fig. 2).

\section{Interscapular brown adipose tissue weight and uncoupling protein-1 protein content}

Although no differences between both experimental groups were found in IBAT weight $(0 \cdot 35$ (SEM 0.03) $\mathrm{g}$ in the linoleic acid group $v .0 \cdot 33$ (SEM 0.01) g in the CLA group), trans-10, cis-12-CLA induced a significant increase in the amount of UCP1 $(P<0.05)$ (Fig. 3).

\section{Discussion}

It has been widely demonstrated that trans-10, cis-12-CLA induces a strong reduction in body fat accumulation in rodents. The extent to which this CLA isomer reduces adipose tissue size depends on several factors, such as the animal species. Thus, the sensitivity of rodents to CLA is as follows:

Table 2. Expressions of enzymes and their regulatory transcription factors in perirenal and subcutaneous adipose tissues from adult hamsters fed on the experimental diets for 6 weeks (Mean values with their standard errors for eight hamsters per group)

\begin{tabular}{|c|c|c|c|c|c|c|c|c|}
\hline & \multicolumn{4}{|c|}{ Perirenal } & \multicolumn{4}{|c|}{ Subcutaneous } \\
\hline & \multicolumn{2}{|c|}{ LA group } & \multicolumn{2}{|c|}{ CLA group } & \multicolumn{2}{|c|}{ LA group } & \multicolumn{2}{|c|}{ CLA group } \\
\hline & Mean & SEM & Mean & SEM & Mean & SEM & Mean & SEM \\
\hline \multicolumn{9}{|l|}{ Enzymes } \\
\hline LPL & 1.00 & 0.47 & 0.48 & 0.4 & 1.00 & 0.53 & 0.75 & 0.28 \\
\hline$A C X$ & 1.00 & 0.47 & 2.08 & 0.28 & 1.00 & 0.23 & 1.46 & 0.42 \\
\hline FAS & 1.00 & 0.45 & 2.05 & 0.30 & 1.00 & 0.60 & 1.97 & 0.39 \\
\hline \multicolumn{9}{|c|}{ Transcription factors } \\
\hline PPAR $\gamma$ & 1.00 & 0.37 & 0.65 & 0.60 & 1.00 & 0.59 & $1 \cdot 12$ & 0.34 \\
\hline SREBP-1a & 100 & 0.48 & $1 \cdot 73$ & 0.15 & 1.00 & 0.20 & $1 \cdot 24$ & 0.34 \\
\hline SREBP-1C & 1.00 & 0.14 & 0.87 & 0.25 & 1.00 & 0.61 & $1 \cdot 21$ & 0.29 \\
\hline
\end{tabular}

LA group, group fed a linoleic acid diet, used as a control; CLA group, group fed a conjugated linoleic acidsupplemented diet; LPL, lipoprotein lipase; ACX, acetyl-CoA carboxylase; FAS, fatty acid synthase; SREBP, sterol regulatory element-binding protein.

${ }^{*}$ Results are shown as mRNA levels expressed as arbitrary units. 


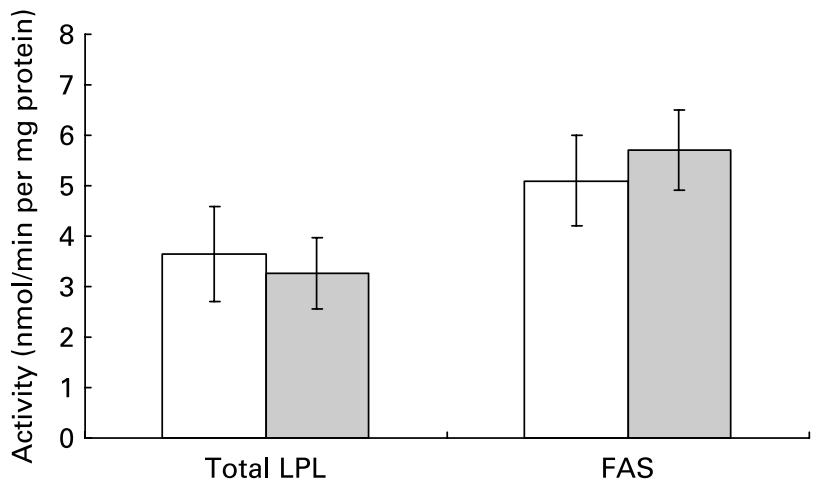

Fig. 2. Total lipoprotein lipase (LPL) activity ( $\mathrm{nmol}$ oleate released/min per $\mathrm{mg}$ protein) and fatty acid synthase (FAS) activity (nmol NADPH consumed/ min per mg protein) in subcutaneous adipose tissue from adult hamsters (eight per group) fed on the experimental diets ( $\square$, linoleic acid diet, used as a control; $\square$, conjugated linoleic acid-supplemented diet) for 6 weeks. Values are means, with standard errors represented by vertical bars.

mouse $>$ hamster $>$ rat $^{(26-28)}$. Another factor suggested to alter CLA effectiveness is the age of the animals or subjects ${ }^{(29)}$. Nevertheless, little is known about this issue because the vast majority of the studies performed on rodents have used young, growing animals and information concerning the effects of CLA in adult animals is scarce.

In order to address this issue, we designed the present experiment for adult hamsters by using the same experimental protocol as that used in a previous study by our laboratory, carried out using young (aged 9 weeks) hamsters. In that study, trans-10, cis-12-CLA significantly reduced adipose tissue from perirenal $(24-29 \% ; P<0.01)$, epididymal $(21-$ $31 \% ; P<0.05)$ and subcutaneous $(30-43 \% ; \quad P<0.001)$ locations ${ }^{(22,30)}$. In contrast, in the present study, the response of adult hamsters to trans-10, cis-12-CLA feeding was weaker because only the subcutaneous depot was significantly reduced $(21 \% ; P<0.05)$. Perirenal and epididymal depots were reduced (18 and $12 \%$, respectively), but this effect

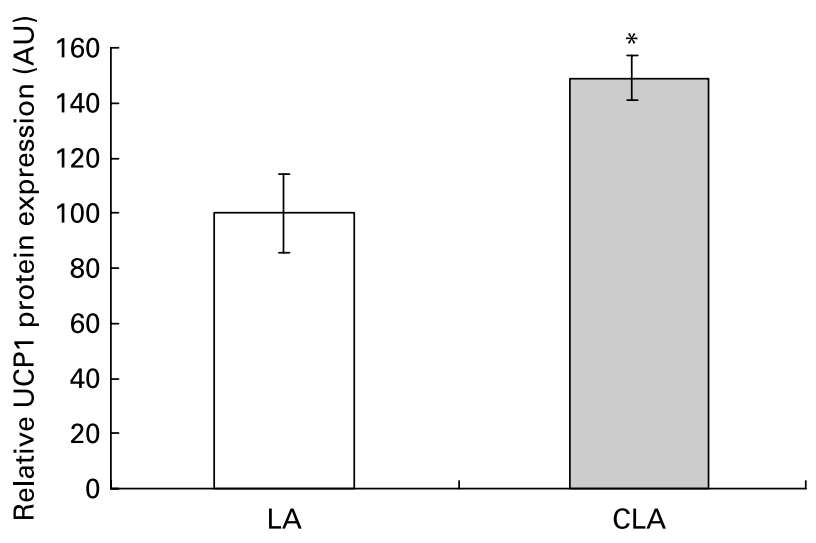

Fig. 3. Relative uncoupling protein-1 (UCP1) protein amount (expressed as arbitrary units; $A U$ ) in interscapular brown adipose tissue from adult hamsters (eight per group) fed on the experimental diets ( $\square$, linoleic acid (LA) diet, used as a control; $\square$, conjugated linoleic acid (CLA)-supplemented diet) for 6 weeks. $\beta$-Actin antibody was used as a loading control to normalise the signal obtained from brown adipose tissue UCP1 protein. Values are means, with standard errors represented by vertical bars. ${ }^{*}$ Mean value was significantly different from that of the LA group $(P<0.05)$. did not reach statistical significance. These results are quite similar to those found in adult rats as compared with young $\operatorname{rats}^{(8,9)}$.

As indicated in the introduction section, numerous studies performed in experimental animals, mainly in rodents, have demonstrated strong reductions of body fat induced by trans-10, cis-12-CLA. However, the effects in human subjects, when these are observed, are less prominent. It must be pointed out that whereas human studies have addressed adults, the vast majority of the experiments performed with rodents have been conducted on growing animals. Taking into account the reduced effectiveness of CLA observed in adult hamsters in the present study, and in adult rats ${ }^{(8,9)}$, it is feasible that one of the reasons explaining the reduced response in human subjects is the adulthood of volunteers.

Several mechanisms of action have been proposed to explain the body fat-lowering effect of CLA. A considerable consensus has been reached concerning the reduction in adipose tissue LPL-mediated fat uptake. Reduced LPL activity in 3T3-L1 adipocytes after supplementation with CLA in the culture medium has been reported in several papers ${ }^{(31-34)}$. In in vivo studies Lin et al. ${ }^{(35)}$ observed that trans-10, cis12-CLA inhibited HR-LPL and Xu et al. ${ }^{(36)}$ reported a significant reduction in both HR-LPL and intracellular LPL activities in adipose tissue from mice fed a diet supplemented with a $0.5 \%$ CLA mixture for a very short experimental period (4d). Accordingly, in our previous study performed in young hamsters, trans-10, cis-12-CLA significantly reduced total and HR-LPL activity, as well as its expression ${ }^{(22)}$. This reduction in LPL resulted in diminished adipose tissue size and explained, in part, the body fat-lowering action of this CLA isomer.

In the present study we analysed the effects of trans-10, cis12-CLA on LPL and its regulating transcriptional factor PPAR $\gamma$ expression in adipose tissue, to determine the potential involvement of this enzyme in the reduction of CLA effectiveness observed in adult hamsters, when compared with young hamsters. Due to the fact that subcutaneous adipose tissue, but not the perirenal depot, was significantly reduced by CLA, these expressions were measured in both fat pads in order to find potential tissue-specific differences. Although the CLA group showed reduced values in LPL expression, this difference did not reach statistical significance $(P=0 \cdot 12$ for perirenal adipose tissue and $P=0.50$ for subcutaneous adipose). No significant changes were found in PPAR $\gamma$ expression in both depots.

Because, as stated before, subcutaneous adipose tissue was significantly reduced, we also measured total and HR-LPL activity in order to find any potential post-transcriptional enzyme activation. No changes in LPL activity were observed. These results suggest that the lack of CLA effect on LPL expression and activity may be one reason that explains the reduced CLA body fat-lowering effect observed in adult hamsters.

With regard to the effects of CLA on adipose tissue lipogenesis, conflicting results have been reported when either enzyme activities or expression were assessed. West et al. ${ }^{(37)}$ observed increased fatty acid synthesis, despite a significant reduction in adipose tissue weight, in growing mice fed a $1 \%$ CLA mixture. Increased lipogenic enzyme activities, without changes in adipose tissue size, were reported in adult 
rats fed $1 \%$ trans-10, cis-12-CLA for 6 weeks by Faulconnier et al. ${ }^{(9)}$. Further, Kang et al. ${ }^{(38)}$ found an increase in FAS mRNA induced by $0.2 \%$ trans-10, cis-12-CLA feeding for 4 weeks in mice. In contrast, Azain et al. ${ }^{(39)}$ did not find changes in FAS activity induced by CLA feeding in rats and other authors found reduced expression of FAS and ACX in mice $^{(40,41)}$

In our previous study performed in young animals, trans-10, cis-12-CLA feeding significantly reduced the mRNA expressions of ACX and FAS ${ }^{(22)}$. In the present study, a tendency towards higher values in the expression of lipogenic enzymes in the perirenal depot was observed $(P=0.09)$ in the CLA group. Nevertheless, changes were not statistically significant in any of the two analysed depots. In line with these data, the expression of SREBP-1a and SREBP-1c, which are the transcriptional factors controlling these two enzymes, remained unchanged. As stated above in this discussion, the subcutaneous was the most sensitive depot. Considering that FAS expression was increased almost two-fold in the CLA group when compared with the linoleic acid group, the activity of this enzyme was assessed in the subcutaneous fat pad, showing no statistical differences.

Taken as a whole, these results suggest that CLA intake affects adipose tissue lipid metabolism in adult hamsters in a different way to young ones. This fact can explain the differences observed in both age groups in terms of CLA effectiveness.

In addition to the direct effects of trans-10, cis-12-CLA on adipose tissue metabolic pathways, other mechanisms have been proposed to explain its body fat-lowering effect. A negative energy balance due to increased energy expenditure may play a role ${ }^{(42-44)}$. IBAT in rodents plays a major role in controlling body weight through diet-induced thermogenesis. This is primarily mediated by the uncoupling of mitochondrial respiration resulting from the marked oxidative capacity of brown adipocytes. To find an explanation justifying the reduction in body fat observed in adult hamsters, in the present study we decided to analyse the effect of trans-10, cis-12-CLA on UCP1 in IBAT. We observed that the animals fed this CLA isomer showed significantly increased amounts of this thermogenin. This effect can result in increased thermogenesis, leading to body fat decrease.

The results published concerning these effects are not very consistent $^{(37,40,44-49)}$. Ealey et al. ${ }^{(45)}$ found significantly lower UCP1 protein levels in brown adipose tissue from mice fed a $1 \%$ CLA mixture compared with controls but increased levels in CLA-fed rats, showing that regulation of UCP by CLA occurs in different manners depending on the animal species. The present results are in good accordance with those found in rats. Nevertheless, in order to make comparisons between these two studies and the present study, it is important to emphasise that whereas we used trans-10, cis-12CLA, the body fat-lowering active isomer, Ealey et al. ${ }^{(45)}$ used a CLA mixture.

In conclusion, these results demonstrate that adult hamsters show little responsiveness to trans-10, cis-12-CLA, which is lower than that observed in young hamsters. One of the reasons explaining this difference is the lack of effect on LPL. More studies are needed to better characterise the effects of CLA on adult animals and to find the reasons explaining this reduction in CLA effect induced by ageing.

\section{Acknowledgements}

The present study was supported by grants from the Ministerio de Educación y Ciencia (AGL2005-02 494), Gobierno Vasco (GIC07/120-IT-265-07; CTP 05/R5), University of País Vasco (GIU06/82) and CYTED (Programa Iberoamericano de Ciencia y Tecnología para el desarrollo). J. M. is a recipient of a doctoral fellowship from the Ministerio de Educación y Ciencia. Palm oil was a generous gift from Agra-Unilever Foods España S.A. (Leioa, Spain).

The contributions of each author were as follows: V. M. R. and E. S. carried out UCP1 Western blot analysis in IBAT; J. M. and I. C. performed RNA quantification by real-time RT-PCR; A. F.-Q. measured LPL enzyme activity; A. F.-Q. and M. T. M. carried out the bibliography revision; M. P. P. supervised the results and manuscript writing.

No conflicts of interest are reported by any of the authors.

\section{References}

1. Wang YW \& Jones PJ (2004) Conjugated linoleic acid and obesity control: efficacy and mechanisms. Int $J$ Obes Relat Metab Disord 28, 941-955.

2. Bhattacharya A, Banu J, Rahman M, et al. (2006) Biological effects of conjugated linoleic acids in health and disease. J Nutr Biochem 17, 789-810.

3. Park Y \& Pariza MW (2007) Mechanisms of body fat modulation by conjugated linoleic acid (CLA). Food Res Int 40, 311-323.

4. Larsen TM, Toubro S \& Astrup A (2003) Efficacy and safety of dietary supplements containing CLA for the treatment of obesity: evidence from animal and human studies. J Lipid Res 44, $2234-2241$.

5. Terpstra AH (2004) Effect of conjugated linoleic acid on body composition and plasma lipids in humans: an overview of the literature. Am J Clin Nutr 79, 352-361.

6. Salas-Salvado J, Marquez-Sandoval F \& Bullo M (2006) Conjugated linoleic acid intake in humans: a systematic review focusing on its effect on body composition, glucose, and lipid metabolism. Crit Rev Food Sci Nutr 46, 479-488.

7. Navarro V, Fernández-Quintela A, Churruca I, et al. (2006) The body fat-lowering effect of conjugated linoleic acid: a comparison between animal and human studies. J Physiol Biochem 62, 137-147.

8. Mirand PP, Arnal-Bagnard MA, Mosoni L, et al. (2004) Cis-9, trans-11 and trans-10, cis-12 conjugated linoleic acid isomers do not modify body composition in adult sedentary or exercised rats. J Nutr 134, 2263-2269.

9. Faulconnier Y, Arnal MA, Patureau Mirand P, et al. (2004) Isomers of conjugated linoleic acid decrease plasma lipids and stimulate adipose tissue lipogenesis without changing adipose weight in post-prandial adult sedentary or trained Wistar rats. J Nutr Biochem 15, 741-748.

10. Park Y, Albright K, Storkson J, et al. (1999) Changes in body composition in mice during feeding and withdrawal of conjugated linoleic acid. Lipids 34, 243-248.

11. Miner JL, Cederberg CA, Nielsen MK, et al. (2001) Conjugated linoleic acid (CLA), body fat, and apoptosis. Obes Res 9, 129-134.

12. Navarro V, Miranda J, Churruca I, et al. (2006) Effects of trans-10,cis-12 conjugated linoleic acid on body fat and serum lipids in young and adult hamsters. J Physiol Biochem 62, 81-87. 
13. Eckel R (1989) Lipoprotein lipase. A multifunctional enzyme relevant to common metabolic diseases. $N$ Engl J Med 320, $1060-1068$.

14. Kersten S (2002) Peroxisome proliferator activated receptors and obesity. Eur J Pharmacol 440, 223-234.

15. Khan S \& Vanden Heuvel J (2003) Role of nuclear receptors in the regulation of gene expression by dietary fatty acids (review). J Nutr Biochem 14, 554-567.

16. Pai J, Guryev O, Brown M, et al. (1998) Differential stimulation of cholesterol and unsaturated fatty acid biosynthesis in cells expressing individual nuclear sterol regulatory element-binding proteins. J Biol Chem 273, 26138-26148.

17. Shimano H (2001) Sterol regulatory element-binding proteins (SREBPs): transcriptional regulators of lipid synthetic genes. Prog Lipid Res 40, 439-452.

18. Horton J (2002) Sterol regulatory element-binding proteins (SREBPs): transcriptional activators of lipid synthesis. Biochem Soc Trans 30, 1091-1095.

19. Himms-Hagen J (1985) Brown adipose tissue metabolism and thermogenesis. Annu Rev Nutr 5, 69-94.

20. Reeves P, Nielsen F \& Fahey GJ (1993) AIN-93 purified diets for laboratory rodents: final report of the American Institute of Nutrition ad hoc writing committee on the reformulation of the AIN-76A rodent diet. J Nutr 123, 1939-1951.

21. Bradford MM (1976) A rapid and sensitive method for the quantitation of microgram quantities of protein utilizing the principle of protein-dye binding. Anal Biochem 72, $248-254$.

22. Zabala A, Churruca I, Fernandez-Quintela A, et al. (2006) Trans-10,cis-12 conjugated linoleic acid inhibits lipoprotein lipase but increases the activity of lipogenic enzymes in adipose tissue from hamsters fed an atherogenic diet. Br J Nutr 95, 1112-1119.

23. Lynen F (1969) Yeast fatty acid synthase. Methods Enzymol 14, 14-17.

24. Livak K \& Schmittgen T (2001) Analysis of relative gene expression data using real-time quantitative PCR and the $2^{-\Delta \Delta \mathrm{CT}}$ method. Methods 25, 402-408.

25. Miranda J, Fernández-Quintela A, Churruca I, et al. (2009) Hepatomegaly induced by trans-10,cis-12 conjugated linoleic acid in adult hamsters fed an atherogenic diet is not associated with steatosis. J Am Coll Nutr 28, 43-49.

26. Kelley DS \& Erickson KL (2003) Modulation of body composition and immune cell functions by conjugated linoleic acid in humans and animal models: benefits vs. risks. Lipids 38, 377-386.

27. Kim MR, Park Y, Albright KJ, et al. (2002) Differential responses of hamsters and rats fed high-fat or low-fat diets supplemented with conjugated linoleic acid. Nutr Res 22, 715-722.

28. Pariza MW (2004) Perspective on the safety and effectiveness of conjugated linoleic acid. Am J Clin Nutr 79, 1132S-1136S.

29. Wahle K, Heys S \& Rotondo D (2004) Conjugated linoleic acids: are they beneficial or detrimental to health? Prog Lipid Res 43, 553-587.

30. Navarro V, Zabala A, Macarulla MT, et al. (2003) Effects of conjugated linoleic acid on body fat accumulation and serum lipids in hamsters fed an atherogenic diet. J Physiol Biochem 59, 193-199.

31. Park Y, Albright K, Liu W, et al. (1997) Effect of conjugated linoleic acid on body composition in mice. Lipids 32, 853-858.

32. Park Y, Storkson J, Albright K, et al. (1999) Evidence that the trans-10,cis-12 isomer of conjugated linoleic acid induces body composition changes in mice. Lipids 34, 235-241.
33. Park Y \& Pariza M (2001) The effects of dietary conjugated nonadecadienoic acid on body composition in mice. Biochim Biophys Acta 1533, 171-174.

34. Park Y, Storkson J, Liu W, et al. (2004) Structure-activity relationship of conjugated linoleic acid and its cognates in inhibiting heparin-releasable lipoprotein lipase and glycerol release from fully differentiated 3T3-L1 adipocytes. J Nutr Biochem 15, $561-568$.

35. Lin Y, Kreeft A, Schuurbiers J, et al. (2001) Different effects of conjugated linoleic acid isomers on lipoprotein lipase activity in 3T3-L1 adipocytes. J Nutr Biochem 12, 183-189.

36. Xu X, Storkson J, Kim S, et al. (2003) Short-term intake of conjugated linoleic acid inhibits lipoprotein lipase and glucose metabolism but does not enhance lipolysis in mouse adipose tissue. J Nutr 133, 663-667.

37. West D, Blohm F, Truett A, et al. (2000) Conjugated linoleic acid persistently increases total energy expenditure in AKR/J mice without increasing uncoupling protein gene expression. J Nutr 130, 2471-2477.

38. Kang K, Miyazaki M, Ntambi J, et al. (2004) Evidence that the anti-obesity effect of conjugated linoleic acid is independent of effects on stearoyl-CoA desaturase 1 expression and enzyme activity. Biochem Biophys Res Commun 315, 532-537.

39. Azain MJ, Hausman DB, Sisk MB, et al. (2000) Dietary conjugated linoleic acid reduces rat adipose tissue cell size rather than cell number. J Nutr 130, 1548-1554.

40. Tsuboyama-Kasaoka N, Takahashi M, Tanemura K, et al. (2000) Conjugated linoleic acid supplementation reduces adipose tissue by apoptosis and develops lipodystrophy in mice. Diabetes 49, 1534-1542.

41. Clement L, Poirier H, Niot I, et al. (2002) Dietary trans-10, cis-12 conjugated linoleic acid induces hyperinsulinemia and fatty liver in the mouse. J Lipid Res 43, 1400-1409.

42. Pariza M, Park Y \& Cook M (2001) The biologically active isomers of conjugated linoleic acid. Prog Lipid Res 40, 283-298.

43. Roche H, Noone E \& Gibney A (2001) Conjugated linoleic acid: a novel therapeutic nutrient? Nutr Res Rev 14, $173-188$.

44. Ryder J, Portocarrero C, Song X, et al. (2001) Isomer-specific antidiabetic properties of conjugated linoleic acid. Improved glucose tolerance, skeletal muscle insulin action, and UCP-2 gene expression. Diabetes 50, 1149-1157.

45. Ealey KN, El-Sohemy A \& Archer MC (2002) Effects of dietary conjugated linoleic acid on the expression of uncoupling proteins in mice and rats. Lipids 37, 853-861.

46. Roche H, Noone E, Sewter C, et al. (2002) Isomer-dependent metabolic effects of conjugated linoleic acid: insights from molecular markers sterol regulatory element-binding protein-1c and LXR $\alpha$. Diabetes 51, 2037-2044.

47. Rodríguez E, Ribot J \& Palou A (2002) Trans-10, cis-12, but not cis-9, trans-11 CLA isomer, inhibits brown adipocyte thermogenic capacity. Am J Physiol Regul Integr Comp Physiol 282, R1789-R1797.

48. Takahashi Y, Kushiro M, Shinohara K, et al. (2002) Dietary conjugated linoleic acid reduces body fat mass and affects gene expression of proteins regulating energy metabolism in mice. Comp Biochem Physiol B Biochem Mol Biol 133, 395-404.

49. Choi JS, Jung MH, Park HS, et al. (2004) Effect of conjugated linoleic acid isomers on insulin resistance and mRNA levels of genes regulating energy metabolism in high-fat-fed rats. Nutrition 20, 1008-1017. 